\title{
Review on Returnee
}

\section{-The Perspective of Dual Social Network, Knowledge Spillover and Institutional-Based View}

\author{
Han Zhang \\ Business Administration College, South China University of Technology, Guangzhou, China \\ Email: zhantina@hotmail.com
}

How to cite this paper: Zhang, H. (2018) Review on Returnee-The Perspective of Dual Social Network, Knowledge Spillover and Institutional-Based View. American Journal of Industrial and Business Management, 8, 2344-2363.

https://doi.org/10.4236/ajibm.2018.812157

Received: November 8, 2018

Accepted: December 16, 2018

Published: December 19, 2018

Copyright $\odot 2018$ by author and Scientific Research Publishing Inc. This work is licensed under the Creative Commons Attribution International License (CC BY 4.0).

http://creativecommons.org/licenses/by/4.0/

\begin{abstract}
With the deepening and rapid development of China's economy, returnees increasingly participate in the operation of enterprises. Based on the literature review of returnees, it is found that returnees have abundant tacit knowledge and special dual social network, which play an active role in innovation, entrepreneurship, internationalization and corporate governance. In addition, capability of management is affected by the institutional environment, so that the improvement of institutional environment can promote returnees to play their own advantages. On the basis of the literature review, two possible future research directions are proposed: a thorough study of returnees from the perspective of institutional-based view and ownership.
\end{abstract}

\section{Keywords}

Returnee, Social Network, Knowledge Spillover, Institutional Environment

\section{Introduction}

Further study abroad has become more and more popular and widespread nowadays in China. With the rapid development of China, more and more students choose to return hometown. Whether the overseas study or work experience of returnees will benefit their personal development and even the development of the companies is also a hot topic of current research. This paper retrieves relevant literatures from 50 Chinese and foreign top journals, then traces back and sorts out the literatures, and summarizes the research processes, directions and future research directions of returnees.

According to Annual Report on the Development of Chinese Students Studying Abroad (2012) [1], after the reform and opening-up in 1978, studying abroad with government funds gradually became a system, and by the end of the 1980 s 
self-funded study reached a new climax. From 1978 to 2000, there were approximate 340,000 Chinese students studying abroad. By the year 2012, there were 1.9 million students studying abroad. It was obvious that China had already become the largest exporter of overseas students in the world. Moreover in 1978-2000, the number of returnees reached 130,000 and in 2001-2011 the number was 688,400; it seemed that most people chose to return China in the early 21 st century. At the same time, the study of returnees also showed a trend of explosion since the 90s of last century. Returnees have become a hot topic in society and it is very necessary for scholars to study the phenomenon of returnees and explore the impact of returnees on enterprises.

Apart from the popularity of returnees, there are also some special characteristics of returnees which are worth studying. Returnees are influenced by the cultural values of at least two countries or regions. Their work or learning experiences span different countries so that they possess transnational social networks. The differences between these and local talents are the basis for the study of returnees.

A increasing number of individuals pay attention to studying or working overseas. What are the excellent characteristics of returnees? Returnees enter the vast number of enterprises after returning home, so, will returnees really bring benefits to business operations due to these characteristics? Generally speaking, scholars believe that returnees will promote the internationalization of enterprises because of special experiences of returnees. But can returnees have broader advantages? The existing studies are more or less related to these aspects, but are very fragmented, without systematic integration. In the existing research, how the differences between returnees and local talents will affect the enterprises is one of the hotspots of the current research, and also has very important practical significance. At present, the phenomenon of returnees mostly exists in eastern developing countries and regions, so that western scholars are not enough concerned about it. Existing international researches on returnees have covered many directions: 1) export performance, 2) entrepreneurship, 3) innovation, 4) technology transfer, 5) social networks, 6) institutional environment. There is little research on dual social networks and institutional environment at present. And studies based on the institutional environment cannot clearly describe the impact on returnees; however, this issue is significant in practice.

Existing researches on returnees are neither enough nor deep enough, the directions of researches, conclusions are also greatly different. There is no systematic literature which can summarize existing results and expound the deeper internal mechanism of returnees. Based on the literature review of returnees, this paper summarizes what advantages the returnees have and what impact they have on enterprises, explores how the institutional environment affects the returnees to exert their own initiative, thus making up for the corresponding theoretical gaps. In China the system will have an important impact on the various business activities, but the existing literature does not pay much attention to the institutional factors. 
This paper proposes future research directions based on the perspective of institutional-based view, which can bring the relative research to a deeper level.

\section{Background}

\subsection{Methodology}

Before describing the issue of returnees, it is necessary to select suitable periodicals first. Chinese periodicals are selected from 30 important management periodicals recognized by the Management Department of National Natural Science Foundation of China in 2006. As to English journals, Gomez-Mejia and Balk in (1992) [2] found that publishing papers in important journals was an important factor affecting the salary of university faculty members. The authors used a TOP21 list of management journals to study. Steve Werner (2002) [3] used the list of TOP20-based management journals to review international management research, excluding Harvard Business Review. This paper follows the list of TOP20 management journals used by Steve Werner (2002) [3]. The research time range is to select the literature published from 2008 to 2017. The key words are "returnees", "returned entrepreneurs", "comeback", "overseas", in Chinese or English. The paper is searched through CNKI and EBSCOand29 literature samples are obtained. Both English and Chinese journals are shown in Table 1.

\subsection{Definition}

The phenomenon of returnees has been studied for a long time, and the causes are complex. Now it is impossible to trace back to the first literature to define "returnee". Many scholars have made their own definitions of returnees. Jielin Dong (2013) [4] proceeds from the essence of returnees which individuals from the country of origin to the country of residence as "overseas" and then return to the country of origin as "returnees". Xiaohui Liu et al. (2014) [5]; Siping Luo (2012) [6] also defined returnees from a geographical perspective, but highlighted the behavioral characteristics during transnational periods: those who returned home after several years of study and work abroad. Later, some scholars defined returnees with their advantages. For example, Dan Wang (2015) [7] summed up the definition of returnees as: returnees are transnational intermediaries that link foreign resources with the institutions of the motherland and bring innovative practices to the institutions of the motherland. Lin Cui et al. (2014) [8] defined returnees from international experience: returnees managers refer to people who have gained a lot of leadership experience abroad before returning to their motherland and have great potential to transfer inexplicit knowledge.

From the definition of scholars, we can see that the definition of returnees or expatriates at the beginning is simply based on the basic level of the existence of transnational migration of these groups. With the deepening academic research on returnees, the definition of returnees is more and more abundant, and em- 
phasizes some advantages of returnees. Based on this, the definition of returnees in this paper is: individuals working or studying abroad for more than one year, and eventually returning home with relevant experience and knowledge, social network, are capability of disseminating tacit knowledge.

Table 1. Journals statistics.

\begin{tabular}{|c|c|c|c|}
\hline Journals & Quantity & Journals & Quantity \\
\hline Academy of Management Journal & 0 & Academy of Management Review & 0 \\
\hline Administrative Science Quarterly & 1 & Decision Sciences & 0 \\
\hline Human Relations & 0 & Industrial and Labor Relations Review & 1 \\
\hline Industrial Relations & 0 & Journal of Applied Behavioral Sciences & 0 \\
\hline Journal of Applied Psychology & 0 & $\begin{array}{c}\text { Journal of International Business } \\
\text { Studies }\end{array}$ & 3 \\
\hline Journal of Management & 0 & Journal of Management Studies & 1 \\
\hline Journal of Occupational Psychology & 0 & Journal of Organizational Behavior & 0 \\
\hline Journal of Vocational Behavior & 0 & Management Science & 0 \\
\hline $\begin{array}{c}\text { Organizational Behavior and Human } \\
\text { Decision Processes }\end{array}$ & 0 & Personnel Psychology & 0 \\
\hline Psychology Bulletin & 0 & Strategic Management Journal & 0 \\
\hline $\begin{array}{c}\text { Journal of Management Sciencesin } \\
\text { China }\end{array}$ & 0 & $\begin{array}{c}\text { System Engineering Theoryand } \\
\text { Practice }\end{array}$ & 0 \\
\hline Management World & 1 & $\begin{array}{c}\text { The Journal of Quantitative \& } \\
\text { Technical Eonomics }\end{array}$ & 0 \\
\hline China Soft Science & 2 & Journal of Finacial Reseach & 1 \\
\hline $\begin{array}{l}\text { Chinese Journal of } \\
\text { Management Science }\end{array}$ & 0 & Journalof Systems Engineering & 0 \\
\hline Accouting Research & 0 & Journal of Systems \& Management & 0 \\
\hline Business Review & 0 & $\begin{array}{c}\text { Journalof Industrial Engineering and } \\
\text { Engineering Management }\end{array}$ & 0 \\
\hline Nankai Business Review & 1 & Science Research Management & 2 \\
\hline $\begin{array}{l}\text { Journal of the China Society for } \\
\text { Scientificand Technical Information }\end{array}$ & 0 & Journalof Public Management & 0 \\
\hline Journal of Management Science & 1 & Forecasting & 0 \\
\hline $\begin{array}{l}\text { Operations Researchand } \\
\text { Management Science }\end{array}$ & 0 & Studiesin Science of Science & 8 \\
\hline China Industrial Economics & 0 & Issues in Agricultural Economy & 0 \\
\hline Chinese Journal of Management & 3 & $\begin{array}{l}\text { Industrial Engineering and } \\
\text { Management }\end{array}$ & 0 \\
\hline Systems Engineering & 0 & $\begin{array}{l}\text { Science of Science and } \\
\text { Management of S \& T }\end{array}$ & 4 \\
\hline R \& D Management & 1 & $\begin{array}{c}\text { China Population Resources } \\
\text { and Environment }\end{array}$ & 0 \\
\hline $\begin{array}{c}\text { Journal of Applied } \\
\text { Statistics and Management }\end{array}$ & 0 & Chinese Rural Economy & 0 \\
\hline Total & & 29 & \\
\hline
\end{tabular}




\section{Advantages of Returnees}

According to the existing researches, returnees have two greatest advantages over native talents: dual social networks and inexplicit knowledge in related fields.

\subsection{Dual Social Network}

Wei Shan, Junguang Gao and Qingpu Zhang (2012) [9] reviewed social network, which social network refers to the aggregation of social actors and their relationships. Granovetter (1973) [10] initiated the theory of "weak tie" and then in 1985 [11] proposed the "embedded" theory. The study of social networks can be divided into two directions. One is that Freeman (1978) [12] and others focus on the overall network analysis, more concretely; the relationship structure of different roles in a group is studied by social econometrics. On the other hand, Granovetter (1973) [10] et al. studied the formation of organizational structure with trust and transaction cost as mediate variables. It focuses on how individual behavior is affected by their interpersonal network and builds community through interpersonal network.

The study of returnees can be classified into the second direction. Granovetter (1985) [11] initiated the embedding theory, then Jones et al. (1997) [13], Nohria and Eccles (1992) [14] applied the embedding theory to strategic and international directions. Jian Qin et al. (2010) [15] argued that organizational knowledge is embedded in the organic system formed of organizational culture, structure and employee network. When returnee entrepreneurs with rich inexplicit knowledge are located in the network system of enterprises, they can transfer their inexplicit knowledge through this network, so that enterprises can acquire new knowledge. Hongjia Ma et al. (2015) [16] social network has a significant impact on individual innovation behavior. Structural hole of an actor's egocentric network will bring the superiority of information and then the actor canbenefit from it.

Generally speaking, one of significant differences between returnees and local talents is social networks. For local talents, their main social network is the local social network; returnees not only have the local social network, but also have a special overseas social network, which makes them gain from structural holes.

Among the existing studies, there is no distinction between the dual social network and local social network at the beginning. At first the researches only prove that the social network of returnees can bring benefits to enterprises. It is generally believed that the domestic social network is the relationship with the local government, suppliers, competitors and scientific research institutes, and the better domestic social network can keep close contact with the relevant government departments, which can alleviate resource constraints. The relationship network with suppliers can shorten the delivery of products with high quality. And the linkage with scientific research institutions are enable enterprises to improve innovation performance. Filatotchev et al. (2009) [17] found that the 
export orientation and performance of SMEs depend not only on the development of R \& D and technology transfer capabilities, but also on the internationalization background of entrepreneurs and international social networks. Returned entrepreneurs can positively promote export orientation and performance.

After that, scholars, especially Chinese scholars, noticed that the social network of returnees had duality. To further subdivide the social network of returnees is necessary. They thought that returnees had local social network and overseas social network, which constituted a special dual social network. The majority of foreign social networks are weak tie networks. Returnees can acquire heterogeneous non-redundant knowledge, which is difficult to obtain from domestic social networks and can bring innovation performance to enterprises. Foreign social networks can also timely access to international market knowledge, tap the local market, and enhance corporate performance. In China, Shusheng Zhang et al. (2013) [18] studied the dual social network of returnees early. The returnees not only work and study in foreign social and cultural situations but also affected by local culture and social. The domestic network was a relational social network, while the foreign network was a social network based on relationship embedding and social structure. Because the main body of the study was entrepreneurial enterprises, the author regarded the social network of returnee entrepreneurs as the social network of entrepreneurial enterprises. The author only puts forward relevant propositions without empirical research. Next, Shaoyu Wu et al. (2016) [19] subdivides the dual social networks into individual social networks and team social networks in detail. The empirical results show that the dual social networks play an important role in enterprise innovation performance with different life cycles. WenZhao et al. (2017) [20], WeiPeng et al. (2017) [21] [22] proposed that the positive effects of dual social networks on returnees should be considered synergistically. There is a matching equilibrium and joint equilibrium between the two social networks, that is, there is a joint effect between the dual social network. Absorptive capacity will affect the balance of enterprises embedded in social networks. When the absorptive capacity of enterprises is insufficient, excessive emphasis on social networks may bring additional burden to enterprises.

It can be seen that the existing researches on the social network segmentation of returnees is an innovative and necessary breakthrough. From the conclusion of the literatures, on one hand, the foreign social network of returnee entrepreneur is one of the motivations for enterprises to promote innovation performance through organizational learning. Generally speaking, western developed countries have advanced educational resources and management ideas. This kind of inexplicit knowledge is hardly absorbed by the enterprises directly due to the organizational boundaries. As a transnational knowledge intermediary, returnees can break through the organizational boundaries and even national boundaries and bring a large amount of inexplicit knowledge into the enterpris- 
es. At the same time, foreign social experience can help enterprises to speed up the process of internationalization. Due to dual cultural embeddedness which is influenced by western culture, society, market and so on, returnees can help enterprises to overcome some of the obstacles to internationalization. On the other hand, the headquarters of enterprise is still in China, so-called "distant water will not quench a fire nearby", the development of enterprises still need to rely on local resources. Xinming Deng et al. (2014) [23] Compared with the non-political collection private enterprises, the internationalization strategy implemented by the political collection private enterprises are more likely to bring about the improvement of corporate performance and the resources of production-study-research, and promote the increase of patent; JiGao Zhu (2015) [24]. The establishment of bank connection of enterprises can significantly increase the total amount of bank loans. Therefore, the local social networks of TMT teams are more helpful in providing more resources to the organization.

\subsection{Inexplicit Knowledge in Related Fields}

In addition to the particularity of social network and its positive impact on enterprises, overseas talents' experience and knowledge in related fields, especially a large number of inexplicit knowledges, can also bring benefits to enterprises. The invisible experience of returnees includes technical experience, advanced management concepts, understanding of overseas markets and so on. There are two management theories that explain the importance of inexplicit knowledge: knowledge spillover and Upper Echelons Theory.

The first is knowledge spillover. Yong Zhaoand Yongxiu Bai (2009) [25] made a review of knowledge spillover, which shows that Arrow (1971) [26] first expounded knowledge accumulation and its economic implications. Later, Romer (1986) [27] innovatively introduced knowledge as an independent factor into the production function and established an endogenous growth model of knowledge spillover. However, the next researches are limited to business administration study, which doesn't show the role of knowledge spillover significantly. In order to break through the bottleneck, scholars turn to space research. There are two main research directions. The first one is to explain the mechanism of knowledge space spillover, such as Jaffe et al. (1993) [28], Adams and Jaffe (1996) [29], Audretsch and Feldman (1996) [30] discussed the mechanism and influencing of knowledge spillover in promoting agglomeration and innovation from different perspectives of patent citation, innovation output and spatial distribution of innovation activities. The second research direction is to study the role of knowledge spillover in urban and regional economic growth by taking innovation and agglomeration as intermediate variables.

The returnee researches belong to the first research direction. According to the knowledge-based view developed from the resource-based view, Zhengqun Zhan and Fei Li (2006) [31] hold that the core competence of an enterprise lies in inexplicit knowledge. Because of the different environment and organization- 
al culture, different inexplicit knowledge and competitive advantages are owned by enterprises. Knowledge management is to absorb inexplicit knowledge and eventually code it into explicit knowledge and bring performance to the enterprise. Network is an important source for enterprises to acquire knowledge. Enterprises can acquire tacit knowledge from competitors and strategic alliances.

As a compound talent, returnees not only possess advanced technical knowledge, but also have transnational experience and knowledge, which is an important way for enterprises to acquire tacit knowledge. Almeida and Kogut (1999) [32] empirically studied the movements of technical talents (patent holders) to promote technological progress in the early stage. However, the object of their study mobile only inter-state in the United States, not like returnees, but it provides a theoretical basis for the transnational technology transfer mechanism of returnees. Next, Filatotchev et al. (2009) [17] elaborated that returnees' mobility mechanism will bring opportunities for technological innovation. Dan Wang (2015) [7] shows that both the foreign and domestic cultural embeddedness are important factors to positively affect the process of knowledge transfer and there is interaction between them. In addition, the presence of other returnees by domestic companies reduces the success of knowledge transfer, which is enhanced if returnees have a similar industry background.

Upper Echelons Theory is another theory that explains the function of foreign experience. Hambrick et al. (1984) [33] put forward the Upper Echelons Theory that the knowledge, values, cognition and psychological preferences of TMT would play an important role in the strategic choice of enterprises. JianhongTao et al. (2013) [34] summarized the Upper Echelons Theory, which shows that the personal characteristics of TMT will ultimately affect the strategic positioning and orientation of enterprises, innovation ability, illegal behavior and other aspects of enterprise.

JianboSong et al. (2016) [35] believe that returned directors have a deeper understanding of the concept of independent innovation and are more willing to accept new ideas to promote enterprise innovation. Wen Wen et al. (2017) [36] believe that European and American countries have a relatively mature social responsibility system, and returnees will pay attention to corporate social responsibility after returning motherland.

With the deepening of research, scholars have studied the inexplicit knowledge in more detail. Overseas experience knowledge covers a wide range, not only the experience of returnees but also overseas market knowledge, technical knowledge and management knowledge. For example, Min Zhu et al. (2013) [37] proved by econometric model that returnees have significant FDI technology spillover effect, which is quite different among different regions. Yi'an Chen (2016) [38] also proved that this effect will be limited by the level of financial market development. Yingyu Wu et al. (2017) [39] proved that overseas experience can promote technology transfer and integration after overseas M \& A. Yuting Sun et al. (2016) [40] prove that returnee graduates, especially postgra- 
duates and doctoral students, have human capital advantages such as foreign language, international cultural knowledge, high professional knowledge and skills, and can get higher salary and promotion than native graduates. Jinyu Meng et al. (2017) [41] proved that knowledge transfer was an important channel of knowledge innovation.

From the above studies, it is not difficult to find that returnees can act as transnational intermediaries which can bring a large amount of tacit knowledge that covers every aspect of business activities, so that enterprises can access to technological upgrading, accelerated internationalization process and others. In addition, the effect of returnees is not only better than other means of technology spillover, including FDI, exports, etc., but also cheaper and easier to operate. Compared with other means, returnees improve the human capital of enterprises; on the one hand, it also brings the role of technology spillover.

\section{What Can Returnees Bring?}

\subsection{Innovation}

Innovation is one important aspect of the advantages brought by returnees and innovation performance and innovation results are the most typical ones. Xiaohui Liu et al. (2010) [42] believed that returnees possessed professional technical knowledge and could transfer knowledge. Moreover, with the relational and structural resources through overseas social networks returnees can promote the innovation of enterprises. For enterprises without returnee entrepreneurs, when there are high-density returnees in their industries, the knowledge spillover effect of returnees can also promote the innovation performance of these enterprises. Similarly, the mobility of employees in the industry can also promote the innovation performance of enterprises. Siping Luo, Yongda Yu (2012) [6] argue that technology transfer is an important means of influencing technological innovation, including export, FDI, returnees, etc. In addition, returnees themselves can improve the level of human capital, the consciousness of patent protection, so that effectiveness of knowledge transfer through returned entrepreneurs is better than others particularly in private enterprises. Jianbo Song et al. (2016) [35] believed that the directors with overseas working experience could master professional and advanced management skills and performance better than those directors without overseas experience, so that could promote the innovation performance of enterprises.

Not only will innovation performance and innovation achievements be improved, but also innovation consciousness which will enhance the innovation of companies and even the industries. Shusheng Zhang and Jixiang Chen (2013) [18] focuses on organizational learning. It is believed that the dual social network of returnees contains a large amount of tacit knowledge, which transforms into technological innovation achievements of enterprises through organizational learning. On the basis of previous research, Shusheng Zhang and Jixiang Chen (2014) [43] further subdivided organizational learning and dual social networks: 
weakties of overseas social network are beneficial to exploratory learning, while strong ties are beneficial to exploitative learning. Domestic social networks are subdivided into commercial relations and political relations. A model of organizational learning to promote innovation by subdividing social networks is constructed. Xindong Zhang and Jing Wu (2016) [44] believe that returnee entrepreneurs have some comprehensive and excellent characteristics: innovative ideology, optimistic psychological capital, extensive international network, and unique technical knowledge structure. These co-effects directly promote the innovation performance of enterprises, which is more significant in the innovation industry, but also have a positive impact in the non-innovation industry, which shows that returnees can help the transformation and upgrading of the industry. Wei Peng and Zhengping Fu (2015) [45] believe that the dual social network of returnees is an incomparable advantage for local entrepreneurs in terms of action strategies. The innovation motivation of returned entrepreneurs is higher than that of local entrepreneurs, and the management style also combines the west with the east.

The various researches show that the advantages of returnees are manifested in many aspects: heterogeneous technological knowledge, overseas social network, international vision, innovation consciousness, etc. These characteristics work together to make returnees show inconsistencies with local talents, and ultimately brings innovation to enterprises. Innovation input, innovation output and innovation efficiency of enterprises are visible results, the role of returnees in innovation can also radiate to the surrounding enterprises, the same industry and even cross-industry.

\subsection{Entrepreneurship and Business Model Innovation}

Returnees are full of entrepreneurial passion and tendency. Because of excellent core capacity they are far more likely to start businesses. JielinDong (2013) [4] finds through case study that the high-tech returnee entrepreneurship team has high entrepreneurial, technological capabilities and tendency to internationalize with the focus on business opportunities in international market. Returned entrepreneurs rely more on experience and ability to create entrepreneurship opportunities and local entrepreneurs pay more attention to social networks. Qi Miao et al. (2015) [46] investigates the entrepreneurial intention of returnees from two aspects: human capital and technological capital. Human capital is subdivided into educational background, working life and entrepreneurial experience, and technological capital is subdivided into technology, patent and business model. Finally, the author draws a conclusion that all the subdivisions of human capital and technological capital will increase the possibility of returnee entrepreneurship. Daomi Lin et al. (2016) [47] because of information asymmetry, returnees with the advantage of information arbitrage can easily accept information and grasp opportunities better. When returnees bring back advanced knowledge (technical knowledge and business knowledge), it can help narrow 
the technological gap between domestic and foreign countries, and thus increase the possibility to start businesses.

In addition, entrepreneurship learning as a mediator variable can extract more new ideas suitable for the development of the Chinese market. Wei Peng and Zhengping Fu (2015) [45] summarized the process model of returnee entrepreneurships through inductive research. The overseas experience and grand dream are the key elements of entrepreneurship, but they also need perseverance and opportunity to really carry out entrepreneurship activities. Moreover, further deepening of strategies needs dual network embeddness, innovative behavior and multi-management practice.

Furthermore, returnees can promote the performance of entrepreneurial enterprises and even the innovation of business models. Qing Liu et al. (2013) [48] find that returned talents with more advantages than local talents have a positive impact on the performance of private entrepreneurship enterprises. Lexin Yun et al. (2014) [49] believed that overseas social networks were embedded in market networks and technological networks. The former helped to design new profit distribution mechanisms, while the latter helped to put forward new value propositions and resource integration methods. The overseas industry experience of returnees was conducive to generating new value propositions, and the overseas functional experience was conducive to generating new resources integration, that are the direct result of the innovation of business mode.

It is worth mentioning that the results of a few scholars show that returnees have negative effects on entrepreneurial performance. For example, Jian Chen et al. (2017) [50] regards the enterprises established by returnees in Zhongguancun for more than eight years as a research sample. The author believed that returnees were not familiar with the current domestic market due to long-term abroad life. Local entrepreneurs with a close relationship with government and financial institutions could obtain a large number of $\mathrm{R} \& \mathrm{D}$ resources. Therefore, returnees do not necessarily improve the performance of start-ups, but the author also finds that overseas returnees with high academic qualifications can weaken the "outsider disadvantage", which means that the knowledge capital of returnees is still a valuable invisible asset.

The majority of research results show that returnees have a positive impact on the performance of start-ups and have a greater willingness to self-employed, which benefits from the rich knowledge and experience. Even if Jian Chen et al. (2017) [50] drew the conclusion that the performance of overseas returnee ventures was weaker than that of local ventures. They also affirmed the enthusiasm of overseas returnees for technological innovation: overseas returnees pay attention to the protection of technological patents.

\subsection{Internationalization}

It is obvious that returnees are conducive to internationalization, because they are familiar with foreign markets. Filatotchev et al. (2009) [17] studied found 
that the existence of returnee entrepreneurs in the company positively affected the internationalization performance of enterprises, due to experience, knowledge and quickly aware of opportunities of foreign markets. It is said that an entrepreneur with multiple experience and knowledge is an intangible asset that can drive the company forward. Lin Cui et al. (2014) [8] studied returnees from the perspective of "grafting" referring to the process in which local enterprises especially in emerging markets could acquire empirical knowledge by employing returnee managers. The research results show that the internationalization experience of returnees can promote the process of enterprise internationalization, at the same time the positive role will be enhanced when the enterprise is a state-owned or private enterprise, while the role will be weakened when the enterprise is a local state-owned or foreign enterprise.

The internationalization experience of returnees can naturally contribute to the internationalization of enterprises. The international market is full of more uncertainties. The returnees themselves are better than the native talents in terms of language and understanding of the overseas market so that it is also more beneficial to the internationalization of enterprises.

\subsection{Corporate Governance}

In terms of corporate governance, foreign value and culture value make returned top management team are different from local talents in detail. Wen Wen et al. (2017) [36] believed that western countries had stronger awareness of social responsibility, and returnees could promote their companies to fulfill their social responsibility under such circumstances. Empirical results showed that the more returnees the top management team had, the higher the social responsibility score and the better rating. It can promote enterprises to better establish their own image so as to indirectly support the operation and development. Wei Peng et al. (2017) [21] [22] combined strategic orientation of enterprises with returnee talents. Technology-oriented and market-oriented enterprises have a positive impact on the embeddness of social networks.

There are few literatures on returnees from the perspective of corporate governance. The reason is that returnee is minority group in enterprise, so that it is difficult to play a particularly significant role in corporate governance. For example, Wen Wen et al. (2017) [36] chose the new aspect of social responsibility and it was proved that returnees played a positive role in corporate governance due to absorbed the management ideas of western countries. But it is difficult to quantify the differences between Chinese and western management models as well as to conduct empirical research, which makes this study weak.

\section{What Factors Can Influence Returnees to Play Their Own Advantages?}

The system is the most important factors that influence the returnees. China's institutional environment affecting the innovation of enterprises is very special. 
In other words, enterprise development is faced with different institutional environment caused by different regions. Chuanlin Shao (2015) [51] believes that a good institutional environment will promote innovation activities and performance of enterprises from both internal and external aspects by various ways such as: reducing the cost of protecting innovation achievements, the allocation of human capital in productive and non-productive behaviors, innovation investment activities through corporate governance. In addition, the forms of Chinese enterprises are different from those of most developed countries due to dense state-owned enterprises. Therefore, it is possible to make a more detailed study of the returnees in different institutional environments from the perspective of institutional based view. Ping Zeng et al., (2016) [52] the high level of institutional development in a region generally means a higher level of marketization and a less government intervention, which will have an impact on enterprises. Yi'an Chen (2016) [38] finds that the size and direction of knowledge spillover effect are based on the Threshold Effect of regional financial development level. That is, on one hand, excessive returnee talents are useless to promote regional technological progress with lower level of financial development. On the other hand, returnee talents will normally play their roles with relatively higher level of financial development. It is because that lower financial markets cannot provide necessary financial supports for venture financing. Jian Chen et al. (2017) [50] believe that human capital and innovative capital could be better developed under the perfect institutional environment. The existing intellectual property protection system in China cannot meet the requirements of returnees' protection of technology patents.

The policy on returnees will also affect the entrepreneurial enthusiasm of returnees. For example, Ping Li and Jiayun Xu (2011) [53] prove that the better the development of financial markets and the higher the financing efficiency, the more returnees will choose to return home to start their own businesses. Qi Miao et al. (2015) [46] on one hand, returnees are willing to return home and start businesses because of good domestic development prospects. On the other hand, returnees engaged in secondary industry are more likely to start businesses. Daomi Lin et al. (2016) [47] found that the knowledge transfer on returnee entrepreneurship was positively promoted by the perceived domestic policy support. YutaoSun et al. (2017) [54] finds that the policy of young academic talents introduction plays a positive role in attracting high-level overseas talents back to China.

Returned talents have many special characteristics which can bring innovative vitality to enterprises and academia, but the external environment will affect the effect. Firstly, the development of financial market has a great relationship with the entrepreneurship. Secondly, talent introduction policy and entrepreneurship policy can attract overseas talents to return and start businesses. But blind introduction of returnee entrepreneurship in regions with underdeveloped financial markets may not have a positive effect on the local economy. To improve the 
institutional environment in all aspects, the government can focus on talent introduction policy, financial market system, intellectual property protection system, market opening policy and so on. On one hand, it is necessary to attract overseas talents return home for development, on the other hand, to promote the knowledge spillover and innovation effect of returnees.

\section{Future Research Directions}

After sorting out and summarizing the literature, this paper also summarizes the possible research directions in the future, mainly from the perspective of the institutional environment.

\subsection{The Influence of Regulation Policy on Returnees}

Scott, (2001) [55]; Hailin, Lan et al. (2010) [56] the system is divided into regulatory system, normative system and cognitive system. Among them, the regulatory system has the greatest impact on returnees. Peng (2003) [57], as a representative of a group of strategic management scholars, studied the relationship between institutional transformation and strategic choice in emerging economies, and regarded system as the third important variable besides industry, enterprise resources and capabilities. Yajun Wu (2010) [58] another group of strategic scholars advocated the integration of institutional logic in the sociological sense with other strategic theories.

The exploration of regulatory system can be discussed from two aspects: the intensity of regulation system and the policy of foreign investment. Hailin Lan, etc., (2010) [56] in terms of the intensity of the regulation system, the legal rules have two sides. On one hand, strong regulation means low uncertainty, that is increasing barriers to innovation and diversification. On the other hand, low regulation is easy to attract foreign investment and develop new industries, but at the same time, the protection of corporate interests will be reduced. Lower barriers to entry enable returnee start-ups to develop new markets. With the strengthening of regulation, it can effectively protect the legitimate interests of enterprises, such as the protection of innovation results. But when the regulation is more stringent, it will bring adverse effects on the development of enterprises. How to balance the relationship between the intensity of supervision and the protection of interests is a difficult problem.

Hailin Lan et al., (2010) [56] foreign investment policies include restrictive policies and guiding policies. Some returned executives come to motherland with the introduction of funds. When local governments provide guiding policies, the more suitable the financial policies are for the returnees to invest in the country. On the contrary, when the local government adopts restrictive policies, returnees who perceive high barriers to entry are unwilling to invest.

The above inferences have not been proved by relevant empirical research literature, so future research direction can aim to the fact that how returnees to play their initiative under different regulatory systems. 


\subsection{The Influence of Ownership on Returnees}

The factor of ownership must be taken into account in the management problem in the Chinese context. Shanxing Gao et al., (2013) [59] there are mainly three forms of ownership in China: state owned enterprises, private enterprises and foreign-funded enterprises. Different ownership enterprises are facing different institutional environments.

Ping Zeng et al., (2016) [52]; Ping Zhang, (2015) [60] in addition to the basic profit goals, state-owned enterprises usually have political goals, including promoting the local economy and increasing employment. When the contradiction is between the two goals, the financial performance goals often give way. In addition, there is a strong administration-oriented in the appointment of senior managers in state-owned enterprises. But on the plus side, through the government, state-owned enterprises can obtain some scarce resources to help them operate and even turn the crisis into safety in times of difficulty. The advantages of social network are bound to be affected because of political connection in state-owned enterprises.

On the contrary, private enterprises and foreign-funded enterprises face less political objectives and connections, and they rely more on market. For private enterprises, their access to resources is far less abundant than that of state-owned enterprises, and most of them are less competitive than multinational companies. Therefore, private enterprises will be particularly sensitive to access to resources and are eager to returnees with the dual social network and tacit knowledge.

For foreign-funded enterprises, employees may have cultural differences, which are not suitable for the management mode of foreign-funded enterprises. Xiliang Feng (2002) [61] sorted out the pressures that employees may face in foreign-funded enterprises as follows: cultural differences, language differences, pressure to change managers frequently and so on. Therefore, returnees will rely on their own cultural embeddedness to better integrate the cultural differences between China and the other countries. Overseas social networks of returned talents will have an impact on enterprises.

Therefore, the study based on ownership can be subdivided into different forms of ownership. What paths do returnees pass to bring innovation, internationalization and other excellent performance for enterprises and whether the process of exerting superiority ability is affected are worthy propositions in the future.

\section{Conclusions}

The researches on returnee are actually combinations of previous studies. Previous studies have proved that social networks can promote innovation and internationalization of enterprises, and knowledge spillover can also promote technological innovation of enterprises. Returnees, as a special group, have not only transnational social networks, but also their special employment and learn- 
ing experience which make them bring technology spillover and knowledge spillover effects to enterprises.

At present, most of the studies on returnees either study the advantages of returnees or explore the impact of returnees on enterprises and universities. Based on the literature review, the following four conclusions are drawn:

First of all, returnees have two excellent advantages: dual social networks and abundant tacit knowledge. In terms of dual social networks, the first step of research focused on that intensive social networks could effectively enhance corporate innovation performance and outputs. And then, Chinese scholars divided the social networks of returnees into domestic social networks and foreign social networks, not only separately studied different social networks for enterprises, the synergy of dual social networks was also discussed. As for inexplicit knowledge, the knowledge can be transmitted across borders and organizations to enterprises and become explicit knowledge. From the perspective of Upper Echelons Theory, tacit knowledge of returnees with various characteristics, consciousness and values can influence the strategy of enterprises.

Secondly, returnees can bring four advantages to enterprises through tacit knowledge and social network. The first is innovation. Returnees group is an important channel to disseminate tacit knowledge. Next, returnees can promote entrepreneurship or business model innovation. Overseas universities pay more attention to entrepreneurship education than domestic universities, and the domestic development environment is getting better and better. All these promote the positive effects on the performance of entrepreneurship enterprises. Moreover, internationalization: overseas experience of returnees can help enterprises explore international market. Finally, returnees can affect the strategic choice and corporate governance of enterprises.

Third, the system has great influence on the initiative of returnees. Only when the financial development reaches a certain level can overseas returnees effectively play their advantages. Domestic talent introduction policy is also an important factor to affect the development of returned talents. When returnees perceive the favorable policies, they will be more inclined to return home and start businesses, which also bring some enlightenment for government to introduce returned talents.

Finally, the direction of future research can focus on the regulation system, and specifically study how the intensity of the regulation system and foreign investment policies affect returnees to play their own advantages. In addition, ownership is also a direction worthy of study. Returnees may play an innovative role in enterprises through different paths under different ownership, which can be studied in the future.

This paper makes up for the blank of the literature review on returnees. By summarizing literatures, the following problems are clarified: what advantages returnees have, what role they can bring to enterprises, and how the system will affect returnees to play their own advantages. At last this paper puts forward possible research directions in the future. 
There are also some shortcomings in this paper. At present, there are few studies on returnees and this paper is limited to the framework established by existing research institutes. In the future, more viewpoints, perspectives and theories need to be integrated to explore the returnees in a deeper level and in many ways, so as to provide help and guidance for the vast number of returnees and enterprises in China. However, there are no relevant empirical studies to prove the point of view for the two research directions proposed in the future. In the future, relevant in-depth studies are still needed to explain various effects of returnees on enterprises.

\section{Conflicts of Interest}

The author declares no conflicts of interest regarding the publication of this paper.

\section{References}

[1] Wang, Y. (2012) Annual Report on the Development of Chinese Students Studying Abroad. Social Science Academic Press, Beijing.

[2] Gomez-Mejia, L.R. and Balkin, D.B. (1992) Determinants of Faculty Pay: An Agency Theory Perspective. Academy of Management Journal, 35, 921-955.

[3] Werner, S. (2002) Recent Developments in International Management Research: A Review of 20 Top Management Journals. Journal of Management, 28, 277-305. https://doi.org/10.1177/014920630202800303

[4] Dong, J. (2013) The "Born Global" Entrepreneurship in China-Case Studies of the High-Tech Start-Ups Established by the "1000 Plan" Diaspora Entrepreneurs. China Soft Science, No. 4, 26-38

[5] Liu, X., Lu, J. and Choi, S.J. (2014) Bridging Knowledge Gaps: Returnees and Reverse Knowledge Spillovers from Chinese Local Firms to Foreign Firms. Management International Review, 54, 253-276. https://doi.org/10.1007/s11575-013-0185-0

[6] Luo S. and Yu, Y. (2012) Technology Transfer, Returnees and Technological Innovation: An Empirical Study Based on China's Photovoltaic Industry. Management World, No. 11, 124-132.

[7] Wang, D. (2015) Activating Cross-Border Brokerage: Interorganizational Knowledge Transfer through Skilled Return Migration. Administrative Science Quarterly, 60, 133-176. https://doi.org/10.1177/0001839214551943

[8] Cui, L., et al. (2015) Leadership Experience Meets Ownership Structure: Returnee Managers and Internationalization of Emerging Economy Firms. Management International Review, 55, 355-387. https://doi.org/10.1007/s11575-014-0221-8

[9] Shan, W., Gao, G. and Zhang, Q. (2012) Review of Corporation Tacit Knowledge Management from the Perspective of Social Network. Science \& Technology Progress and Policy, 29, 156-160

[10] Granovetter, M.S. (1973) The Strength of Weak Ties. American Journal of Sociology, 78, 1360-1380. https://doi.org/10.1086/225469

[11] Granovetter, M. (1985) Economic Action and Social Structure: The Problem of Embeddedness. American Journal of Sociology, 91, 481-510. https://doi.org/10.1086/228311

[12] Freeman, L.C. (1978) Centrality in Social Networks Conceptual Clarification. Social 
Networks, 1, 215-239. https://doi.org/10.1016/0378-8733(78)90021-7

[13] Jones, C., Hesterly, W.S. and Borgatti, S.P. (1997) A General Theory of Network Governance: Exchange Conditions and Social Mechanisms. Academy of Management Review, 22, 911-945. https://doi.org/10.5465/amr.1997.9711022109

[14] Nohria, N. and Eccles, R.G. (1992) Networks and Organizations: Structure, Form, and Action. IEEE Transactions on Systems Man and Cybernetics Part C (Applications and Reviews), 28, 173-193.

[15] Qin J., Wang, Y., Liang, X. and Lu, L. (2010) Driven Factors of Spillover Effects on the MNCs in China-Dual Perspectives of Knowledge-Based View and Embeddedness Theory. Science of Engineering and Management of $S \& T, 31,138-143$

[16] Ma, H., Hou, M. and Song, C. (2015) Social Network, Knowledge Sharing and Individual Innovaive Behavior: The Moderating Role of Dualistic Learning. South China Journal of Economics, 33, 100-113.

[17] Filatotchev, I., et al. (2009) The Export Orientation and Export Performance of High-Technology SMEs in Emerging Markets: The Effects of Knowledge Transfer by Returnee Entrepreneurs. Journal of International Business Studies, 40, 1005-1021. https://doi.org/10.1057/jibs.2008.105

[18] Zhang, S. and Chen, J. (2013) The Research on the Development of China Returnee Enterprise: Ambidextrous Network and Organizational Learning during the Process of Technology Innovation. Studies in Science of Science, 31, 1744-1751.

[19] Wu, S., Wang, B., Li, X. and Wang, D. (2016) Research on the Influence of Double Network to Technology Innovation Performance in Returnees Talents Start-Ups. Science of Engineering and Management of $S \& T, 37,96-106$.

[20] Zhao, W. and Wang, N. (2017) Research on Performance Improvement Path of Chinese Returnees Enterprises Considering Ambidextrous Network: The Fuzzy-Set Qualitative Comparative Analysis. Science of Engineering and Management of $S \&$ $T, 38,128-139$

[21] Peng, W., Tang, K. and Fu, Z. (2017) Study on the Effect of Strategic Orientation on Dual Network Embeddedness of Returnee Entreneurial Firms: Based on the Perspective of Organizational Ambidexterity. Chinese Journal of Management, 14, 1662-1671.

[22] Peng, W., Zhu, Q.K. and Fu, Z. (2017) The Effect of Network Embeddedness Ambidexterity on Returnee Entrepreneurial Performance. Studies in Science of Science, 35, 1359-1369.

[23] Deng, X., Xiong, H., Li, J., Hou, J. and Wu, J. (2014) Political Connection, Internationalization Strategy, and Firm Value: Evidence from the Panel Data of Chinese Private Listed Companies. Nankai Business Review, 17, 26-43.

[24] Zhu, J., Han, F. and Lu, Z. (2015) Industrial Policy, Bank Connections, and Debt Financing: An Empirical Research Based on A-Share Listed Companies. Journal of Financial Research, No. 3, 26-43.

[25] Zhao, Y. and Bai, Y. (2009) Knowledge Spillovers: A Survey of the Literature. Economic Research Journal, No. 1, 144-156.

[26] Arrow, K.J. (1971) The Economic Implications of Learning by Doing. Palgrave Macmillan, London, 155-173.

[27] Romer, P.M. (1986) Increasing Returns and Long-Run Growth. Journal of Political Economy, 94, 1002-1037. https://doi.org/10.1086/261420

[28] Jaffe, A.B., Trajtenberg, M. and Henderson, R. (1993) Geographic Localization of Knowledge Spillovers as Evidenced by Patent Citations. The Quarterly Journal of 
Economics, 108, 577-598. https://doi.org/10.2307/2118401

[29] Adams, J.D. and Jaffe, A.B. (1996) Bounding the Effects of R \& D: An Investigation Using Matched Establishment-Firm Data. Rand Journal of Economics, 27, 700-721. https://doi.org/10.2307/2555878

[30] Audretsch, D.B. and Feldman, M.P. (1996) R \& D Spillovers and the Geography of Innovation and Production. American Economic Review, 86, 630-640.

[31] Zhan, Z. and Li, F. (2006) Knowledge-Based View of the Firm: An Open Dynamic Perspective. Journal of Intelligence, 25, 18-21.

[32] Almeida, P. and Kogut, B. (1999) Localization of Knowledge and the Mobility of Engineers in Regional Networks. Management Science, 45, 905-917.

[33] Hambrick, D.C. and Mason, P.A. (1984) Upper Echelons: The Organization as a Reflection of Its Top Managers. The Academy of Management Review, 9, 193-206. https://doi.org/10.5465/amr.1984.4277628

[34] Tao, J., Shi, P. and Duan, W. (2013) Review on Upper Echelon Theory-Based on Perspective of Cross Level Integration. Science and Technology Management Research, 33, 224-229.

[35] Song, J. and Wen, W. (2016) Can Directors' Foreign Experience Promote Corporate Innovation? China Soft Science, No. 11, 109-120.

[36] Wen, W. and Song, J. (2017) Executives' Foreign Experience and Corporate Social Responsibility. Journal of Management Science, 30, 119-131.

[37] Zhu, M. and Xu, J. (2013) Return of Overseas Talents and FDI Technology Spillover-An Empirical Analysis of the Regional Differences and Impact Factors. Studies in Science of Science, 31, 1663-1670.

[38] Chen, Y. (2016) An Empirical Study of the Relationship between Financial Development and Returnees Reflux Knowledge Spillover Effect. Science Research Management, 37, 168-176.

[39] Wu, Y. and Chen, S. (2017) Will Cross-Border Mergers and Acquisitions Influence Innovation Performance of Emerging Market Firms? - The Effect of TMT International Experience. Studies in Science of Science, 35, 1378-1385.

[40] Sun, Y., Du, Z., Zhao, G. and Li, R. (2016) Do Chinese Overseas Returnees Earn More? Journal of Financial Research, No. 11, 174-190.

[41] Meng, J., Liu, C. and Chen, X. (2017) Performance Measurement for Transnational Knowledge Transfer by Chinese Returned Scholars. Chinese Journal of Management, No. 12, 1855-1861.

[42] Liu, X., et al. (2010) Returnee Entrepreneurs, Knowledge Spillovers and Innovation in High-Tech Firms in Emerging Economies. Journal of International Business Studies, 41, 1183-1197. https://doi.org/10.1057/jibs.2009.50

[43] Zhang, S. and Chen, J. (2014) The Research on the Organizational Learning and Technology Innovation of China Returnee Enterprise Based on Ambidextrous Network: A Multiple Cases Research. Science of Engineering and Management of $S$ $\&$ T, No. 1, 117-125.

[44] Zhang, X. and Wu, J. (2016) Do Research Executives Promote the Technology Innovation in Enterprises? Science of Engineering and Management of $S$ \& T, 37, 115-128.

[45] Peng, W. and Fu, Z. (2015) A Grounded Theoretical Study on Behavior Process of Returnee Entrepreneur: Based on the Examination of National "1000 Plan” Entrepreneurs. Studies in Science of Science, 33, 1851-1860.

[46] Miao, Q., Bao, Y. and Liu, Y. (2015) Impacts of Human and Technological Capitals 
on the Intention to Start Business. Studies in Science of Science, 33, 1035-1042, 1099.

[47] Lin, D., et al. (2016) International Knowledge Brokerage and Returnees' Entrepreneurial Decisions. Journal of International Business Studies, 47, 295-318. https://doi.org/10.1057/jibs.2016.1

[48] Liu, Q., Zhang, C., Lv, R. and Lu, J. (2013) Whether the Performance of Returnees Is Better or Not: Evidence from Chinese Private Enterprises. The Journal of World Economy, No. 12, 70-89.

[49] Yun, L., Yang, J. and Zhang, Y. (2014) The Generation Mechanism of Innovative Business Model Archetypes Based on Entrepreneurship Firms. Chinese Journal of Management, 11, 367.

[50] Chen, J., Liu, X., Qiu, S. and Gao, Y. (2017) Liability of Foreignness and the Moderating Effect of Knowledge Capital. Studies in Science of Science, 35, 1348-1358.

[51] Shao, C. (2015) Institutional Environments Government Fiscal Subsidies and Firms' Innovation Performance-Empirical Analysis of Chinese Industrial Firms. Soft Science, No. 9, 34-37.

[52] Zeng, P., Liu, Y. and Wu, X. (2016) The Impact of Government Support on Enterprises' Technological Innovation: Integration of RBV and IBV. Economic Management, No. 2, 14-25.

[53] Li, P. and Xu, J. (2011) Financial Market Development, Returnees and Technology Diffusion: The Perspective of the Creation of New Enterprises by Returnees. Nankai Business Review, 14, 150-160.

[54] Sun, Y. and Zhang, S. (2017) An Empirical Study on the Policy Effect of Young Academic Brain Gain-An Example of the TYTP Candidates. Studies in Science of Science, 35, 511-519.

[55] Scott, W.R. (2001) Institutions and Organizations. Sage Publications, Thousand Oaks, 69-89.

[56] Lan, H., Wang, X., Wu, X. and Song, T. (2010) Research on Market Entry Mode Selection Based on Institution-Based View: Developing Theoretical Framework and the Propositions. Nankai Business Review, 13, 77-90.

[57] Peng, M.W. (2003) Institutional Transitions and Strategic Choices. Academy of Management Review, 28, 275-296. https://doi.org/10.5465/amr.2003.9416341

[58] Wu, Y. (2010) The Recent Development of Strategic Management Theories in China: Looking Back and Forward from an Indigenous Research Point of View. Chinese Journal of Management, 7, 1692.

[59] Gao, S., Cai, X. and Jiang, X. (2013) The Effects of Two Types Institutional Support on Firm Original Innovation: A Comparison Study of Different Ownership Firms. Science of Engineering and Management of $S$ \& T, 34, 42-52.

[60] Zhang, P. and Huang, Z. (2015) Research on Relationship between Political Connections and Enterprise's Performance: The Influence of Leadership Style. Forecasting, No. 4, 41-46.

[61] Feng, X. (2002) Preliminary Study on Work Stress of Staff in Foreign-Funded Enterprises. Population \& Economics, No. S1, 53-55. 